\title{
The Multiple Meanings of Papal Inscriptions in Late Antiquity and the Early Middle Ages
}

\author{
Thomas F. X. Noble
}

Between the election of Damasus in 366 and the death of Sergius I in 701 a total of eighteen popes placed around seventy more or less legible inscriptions in or near some thirty-two churches or cemeteries inside Rome and in the city's suburbs. The Romans had always had the "epigraphic habit." But in the last decades of the third century and the early decades of the fourth, that habit was much attenuated. There were always more private than public inscriptions. Epitaphs, commemoration of marriages, or temple vows, always outnumbered memorials of legislation or military campaigns. When inscriptions became prominent again in the fourth century private records, and especially epitaphs, once again predominated. ${ }^{1}$ But there was something new. The number of Christian epitaphs soared. New too, beginning with Damasus, were public records of Christian content and import. Christians acquired the epigraphic habit with enthusiasm. I shall focus on the papal display of the habit. But I am pursuing a larger theme here; I wish to say something about the controversial "rise of the papacy."

On the one hand, the papal cultivation of the epigraphic habit of the Roman world was an absolute innovation, at least as far as the papacy was concerned.

1 The scholarship on epigraphy is vast. For fine introductions see: Petrucci (1998), Ramsby (2007), and Handley (2003).

2 This is a huge subject that I can no more than notice here. I am not as skeptical about ideas (that is, the formation of a papal ideology) or the growth of papal institutions as some scholars. For instance, I disagree sharply with Demacopoulos (2013). I disagree in emphasis with Sessa (2012). I by no means accept the wildly exaggerated claims of Ullmann (1970), esp. 1-43. I prefer the more organic and gradualist approaches of scholars such as Caspar (1930) chs. 2-12, Pietri (1991) 219-43, and Maccarrone (1991a) 275-362. I still admire, for both ideas and institutions, Pietri (1976). Valuable on institutions is Saxer (2001) 493-632. There are valuable backward glances in Halphen (1907). For recent treatments see: Friedrichs (2015), Thompson (2015), and Hornung (2015). Papal ideology in the last portion of the period I treat is well presented in Azzara (1997). So, full disclosure: I take very seriously the idea that the popes were self-consciously and increasingly defining the ideological and ecclesiological underpinnings of their office as well as building the public and private institutions necessary to the running of their church in the very years when the inscriptions started and continued to be placed.

(C) THOMAS F.X. NOBLE, 2020 | DOI:10.1163/9789004425682_005

This is an open access chapter distributed under the terms of the CC BY-NC 4.0hlicense. 
Prior to the pontificate of Damasus I (366-384) there is no surviving evidence of epigraphic activity by any bishop of Rome. On the other hand, when Damasus, and then many of his successors, mounted inscriptions around Rome and its suburbs, they were embracing, adapting, appropriating an ancient and established traditional practice. Papal inscriptions could not, would not, have had any meaning or impact if the Roman authorities had not already for centuries announced, boasted of, and taken pride in their achievements by means of epigraphical monuments. And while this essay emphasizes epigraphy, it contextualizes that epigraphy in images, public celebrations, popular assemblies, and construction works. Each of these areas of activity was a central feature of the behavior of Rome's leaders and so papal adaptation of these kinds of activities "anchors" papal innovation in deep, old traditions.

I will attempt to locate the inscriptions in several interrelated historical contexts. I will discuss the popes who put their images in churches, the development of stational liturgies as urban celebrations, the assembling of at least thirty-nine councils in Rome, and the construction or renovation of at least seventy-five churches by no fewer than forty popes. Finally, and somewhat more expansively, I shall discuss what the inscriptions actually say.

Let me conclude these preliminary comments with a few qualifications. I am not going to discuss papal epitaphs, a good many of which survive. They merit study on their own terms but we cannot say for sure, with one exception to which I will come in due course, who is responsible for them and when they were put in place. If, as Michael Borgolte pointed out, the popes had established a necropolis that action would have been a significant sign of institutional awareness and identity. ${ }^{3}$ But they did not do so. Prior to the third century most popes were buried near St Peter's. In the third century several popes were buried in the catacomb of San Callisto. Fourth-century popes chose, or had chosen for them - we do not know which - sites all around Rome and its environs. Beginning in the fifth century a large majority of popes were buried in or around St Peter's but for many centuries this was not the only site of papal burials. ${ }^{4}$ I am not going to discuss fragments, partly because I have not combed through every corpus of inscriptions to find them all and partly because while their existence and location are potentially significant, they convey imprecise messages. Finally, I will not take time to discuss the source of the inscriptions that figure in my remarks. Some are still in place and are

3 Borgolte (1989), 9-11.

4 Borgolte (1989), 15-75. Most of what is known about papal burials and epitaphs may be found in LP. 1 and in Petrus Mallius (1946), 375-442. This work was composed in the time of Alexander III (1159-1181). 
both visible and legible. Some are on slabs of stone, even broken slabs, that are found today far from their original location. Some exist only in various collections prepared at different times during the Middle Ages and the early modern period. It is enough for present purposes to know who mounted a particular inscription, where it is, or was, located, and what it says.

Ramsey MacMullen said this about inscriptions in the high empire but his words seem to me relevant to late antiquity as well: 'with our chosen words we address our whole community, or posterity itself.' It is not surprising that before the Constantinian peace of the church Christians did not call attention to themselves by mounting prominent inscriptions. They probably did not dare to address their own community, much less posterity. But it is not obvious that Christians would have chosen to do so in the more secure conditions of the fourth century. Here is MacMullen again: "The rise and fall of the epigraphic habit was controlled by what we can only call the sense of audience. In their exercise of the habit, people ... counted on their world still continuing in existence for a long time to come, so as to make nearly permanent memorials worthwhile; and they still felt themselves members of a special civilization, proud (or obliged) as such. ${ }^{6}$ Here are several points that will recur in my discussion: audience, permanence, memory, and a special sense of identity. Each of these points will require elaboration.

I begin with the location of the inscriptions that can today be read in publications or in some instances in situ, or else viewed in museums. Thirty-two churches of widely varying size and distinction were sites of papal inscriptions. ${ }^{7}$ That number is a little deceptive because there are numerous fragments, some displaying a few broken lines and some revealing only a handful of letters. These items would significantly expand the repertoire if we could read, place, and date them with specificity. We have thirty basically illegible fragments from Damasus alone. ${ }^{8}$ In several cases our clue as to Damasus's responsibility for the relevant inscriptions is their Philocalian lettering. Furius Dionysius Filocalus was a Roman epigrapher who worked in the second half of the fourth century. He created a particularly beautiful and distinctive script. ${ }^{9}$ The number of churches that had inscriptions must have been a good deal larger than we can now account for. Twelve of the churches with inscriptions, $37.5 \%$, are

5 MacMullen (1982) 244. See also Meyer, (1990) 74-96. Meyer emphasizes, perhaps exaggerates, citizenship as the primary explanation for epitaphs. The only scholar to address the papal inscriptions in anything like the way I attempt to do here is Scholz, (2016) 121-35.

6 MacMullen (1982) 246.

7 These will be discussed below with references.

8 Published, along with the legible ones, by Trout (2015).

9 Ferrua (1939) 35-47, Gray (1956) 5-13, and Trout (2015) 47-52. 
inside the city and twenty, $62.5 \%$, are in the suburbs. Urban churches with inscriptions tend to be either Patriarchal basilicas, the Lateran and Santa Maria Maggiore, or else title churches, for example San Lorenzo in Damaso, Santo Stefano Rotondo, San Pancrazio, Santi Cosma e Damiano, Santa Sabina, or San Pietro in Vincoli. The suburban churches show a good deal of variety. The patriarchal basilicas of St Peter's, St Paul's, and San Lorenzo sport significant numbers of inscriptions. These churches, although they were outside the Aurelian Walls, were integral constituents of Rome's ecclesiastical life. One might almost view them as honorary urban churches. Otherwise, the great majority of suburban inscriptions were placed in cemeterial basilicas and churches, some above ground and some below, some impressive and some tiny, some extant and some long vanished. Overwhelmingly the suburban churches with inscriptions are mentioned in the pilgrim's guides that began to proliferate in the seventh century. ${ }^{10}$ I think this suggests that these inscriptions were seen very often. ${ }^{11}$ The inscriptions inside the city were sometimes monumental and impressive. They must have drawn the eyes of observers. Many of the urban inscriptions, whether or not they are extant in situ, were copied into medieval collections, which suggests that they were objects of real interest Here we have hints about MacMullen's audience. Erik Thunø adds an important point with respect to audience, particularly where the more beautiful and impressive inscriptions are concerned: They possessed both textual and visual significance which would have made them accessible, albeit in different ways, to both the literate and the illiterate. ${ }^{12}$

Why were the inscriptions put where we find them or where later evidence tells us they were located? I find no surprises in the urban churches that have inscriptions but I must confess to being puzzled that there are not more of them. Not all of Rome's seven hills, or seven ecclesiastical regions, have a church with an inscription, so an attempt to blanket the city's ecclesiastical topography does not seem to offer an explanation. The Lateran is Rome's cathedral church so one might well expect various popes to have put their mark on it. They did so a good many times but almost always in the baptistery or in the oratories connected to the baptistery. In so far as baptism was the fundamental rite of entry into the society of Christians, and the Lateran baptistery was Rome's principal one, might the inscriptions there represent a kind of paternal claim by the popes? Santa Maria Maggiore is newer than the Constantinian

\footnotetext{
10 Collected in Codice topografico della città di Roma (1940-43) 4 vols.

11 I explored aspects of this topic in Noble (2013) 205-17. See also Dey (2008) 398-422. A good introduction remains Birch (1998). 
basilica at the Lateran and the cult of Mary developed slowly at Rome. ${ }^{13}$ Perhaps it is not surprising that it has fewer and later antique inscriptions. The suburban churches sometimes proffer clarity and sometimes do not. St Peter was significant to Rome in so many ways that it is not at all surprising that there are a good many inscriptions in and around his great basilica. But appearances are a bit deceiving. Nine of the twelve inscriptions around St Peter's were mounted by Symmachus who was effectively exiled there for about seven years while Laurentius controlled the city. ${ }^{14}$ One almost gets the impression that Symmachus was digging in for the long haul. St Paul's significance is beyond question but his basilica received very few inscriptions. Nearby cemeterial churches got more. Lawrence was Rome's premier post-apostolic martyr so the presence of inscriptions in his basilica occasions no wonder but the tiny number of them does seem odd. Pelagius II rebuilt the basilica in the late sixth century so it is possible that older material was discarded. Damasus prepared epitaphs for his mother and sister at the Cemetery of Marcus and Marcellianus. Apart from commemorations of several of his papal predecessors, to which I shall return, Damasus reserved his elegies for martyrs. ${ }^{15}$ Presumably the location of his inscriptions was dictated by the location of the martyr's graves. One would like to know, but simply cannot, why he chose to commemorate the martyrs he did. Victor Saxer and Marianne Sághy have noted that there is some overlap between the Calendar-Codex of 354 and the martyrs Damasus commemorated. ${ }^{16}$ That is not much to go on. But Sághy also observes that Damasus was interested in peacemakers and in martyrs who had returned to the faith and church after periods as heretics or schismatics. He also had a fondness for paired martyrs - say Chrysanthus and Daria or Nereus and Achilleus. His successors followed his lead and continued for the most part to commemorate martyrs. Precisely why they chose one martyr over another is not known. Almost every one of Rome's radial roads had churches with papal inscriptions. As with the urban memorials so too with the suburban ones, I cannot discern grounds for a topographical argument.

The location of these inscriptions permits some preliminary conclusions. The popes, beginning with Damasus, were unquestionably putting their name

\footnotetext{
13 Still authoritative is Klauser (1972) 120-35. See also de Blaauw (1994), vol. 1, 340-41, noting that the dedication of Santa Maria Maggiore by Sixtus III in 432 was the first tangible sign of devotion to Mary in Rome. See too Rubin (2009) 95-96.

14 The story has been told many times. For a good, recent account see Moorhead (2015) 50-6o. The fullest treatment is Wirbelauer (1993).

15 For wise words on why popes promoted the cult of the martyr, although not on why Damasus chose the ones he did, see Sághy (2015) 37-56.

16 Saxer, (1984) 59-88; Sághy (2000) 277.
} 
prominently and visibly around the region. Jean Guyon once observed that popes put inscriptions on quite a few churches that were imperial projects or the recipients of significant imperial benefaction. ${ }^{17}$ That is true but not all imperial churches got inscriptions and the numbers are not at all even. The fourth and fifth centuries witnessed the inception and then the proliferation of papal building activity and artistic patronage. ${ }^{18}$ The chronological span of papal inscriptions tracks well overall with these other kinds of visible, public display. Taken together they illustrate both the triumph of Christianity in the city of Rome and the rising prominence of Rome's bishops. Where Damasus is concerned, I wonder if he was trying, among other things, to assert his legitimacy after the bloody struggle that accompanied his contested election. ${ }^{19}$ And perhaps, as Marianne Sághy suggests, he saw the martyrs in particular as a 'medium of divine affirmation for his uncertain position as bishop'. ${ }^{20}$ Across the fourth century, and with a quickening pace in the fifth and sixth centuries, Rome's bishops made claims about their authority and slowly built institutions to express and exercise that authority. Some scholars assert that for a long time some areas of the city and some noble families were impervious to papal claims, but the claims are there all the same and I think that the inscriptions, alongside artistic patronage and construction, are one manifestation of those claims. ${ }^{21}$ Manuela Gianandrea offers a more subtle interpretation by insisting that in the fifth century we actually witness a kind of collaboration among bishops, priests, devout and wealthy aristocrats, emperors, and imperial officers. ${ }^{22}$ I will come back to this when I talk about what the inscriptions actually say. Damasus, and then his successors, planted their flags, so to speak, pretty broadly over Rome's suburbs. I see at least two possibilities for thinking about this. First, Damasus made himself, and created an opportunity for his

17 Guyon (1987) 413. Sághy (2000) 278-79 agrees.

18 See most recently and with abundant references Kinney (2017) and Gianandrea (2017), both in Foletti and Gianandrea (2017) 65-97 and 183-216. The chapters by Lucherini, Gianandrea, Guiglia, and Taddei in D'Onofrio (2016) summarize papal artistic patronage and construction work down to Sergius I (687-701). In general see the excellent discussion in Curran (2000) 116-57.

19 The LP 39.1 discreetly passes over the troubles but Ammianus Marcellinus, Rerum Gestarum, 27.3.12-14, Rolfe, ed., vol. 3, 18-20 recounts the details with some relish. For a basic account see Caspar (1930), vol. 1, 196-99.

$20 \quad$ Sághy (2000) 273.

21 For various perspectives on this topic see Sessa (2012) 1-3 and passim; Hillner (2007), 22561. Several of the articles in the Cooper and Hillner collection (2007) bear on the roles of the aristocracy in fourth- and fifth-century Rome. See also Machado and Humphries (2012) in Grig and Kelly (2012) 136-58, 161-82.

Gianandrea (2016): 79-86, 102-105. 
successors, to be impresarios of Rome's cult of the martyrs. This may have been a way of creating new Christian identity for Rome and of placing Rome's bishops squarely in the center of the newly forming community. This just might have been a counter-punch to aristocratic opposition within the city or else a sign of growing papal leadership. Second, the Liber Pontificalis notes in some detail that Sylvester I, Damasus, Innocent I, and Sixtus III bestowed impressive endowments on several of Rome's churches. ${ }^{23}$ The farms and/or revenues that made up those endowments were primarily located in Rome's suburbs. Federico Marazzi's fine study of the patrimony of the Roman Church down to the tenth century tells us a lot about the Sancta Romana Ecclesia in the strict sense and about urban churches more generally. ${ }^{24}$ Chris Wickham's magisterial study of Rome between the ninth and twelfth centuries makes clear the tight and essential bonds between the city and the agro Romano. ${ }^{25}$ At the very time when the popes were proclaiming their presence outside the city, they were beginning to build, renovate, and decorate churches inside the city - and outside too, of course - but from the time of Pope Sylvester down to 891 when the contemporary sequence of the Liber Pontificalis breaks off, about $70 \%$ of all papal construction and donation was inside the city. ${ }^{26}$ I offer therefore the hypothesis that the popes were, by marking the suburbs, building relationships that had fundamental physical and material dimensions - which, of course, is not to deny the spiritual and ecclesiastical dimensions that were crucial for the suburban churches.

Thus far the location of the inscriptions. Let me turn now to another path of inquiry: context. I believe that the signed papal inscriptions can be situated within artistic, liturgical, conciliar, and what might almost be called industrial activities. For purposes of this discussion I shall draw evidence from the pontificates running from Sylvester I (314-335) to Constantine I (708-715). I end with Constantine because I believe that with the election of his successor Gregory II the late antique papacy ended and the medieval papacy began. But that is an argument for another day.

At least nine popes - Liberius, Simplicius, Felix IV, Pelagius II, Honorius, John IV, Theodore, Donus, and John VII put images of themselves in

\footnotetext{
23 LP $34.3-33,39.4-5,42.6,46.3$.

24 Marazzi (1998). For a fine appreciation of Marazzi's work see Costambeys (2000), 367-96 (the article is a double review, also taking into account the book by Azzara in $n .2$ above). For a superb assessment of literally all the scholarship on the papal patrimonies in late antiquity see Moreau (2006) 79-93.

25 Wickham (2015).

26 I surveyed this activity in Noble (2000) $5^{8-73}$.
} 
various churches. ${ }^{27}$ Liberius put his image in an arcosolium in the Praetextatus Catacomb, Pelgius II put his in San Lorenzo, Honorius put his in Sant'Agnese, and John VII put one of his three in the Marian Oratory in Old St Peter's. The rest are in the city: Simplicius in Santa Bibiana, Felix IV in Santi Cosma e Damiano, John IV and Theodore in San Venanzio, Donus in Santa Martina, and John VII in Santa Maria Antiqua and Santa Maria in Trastevere. We have very indistinct gold-glass images bearing the names of Julius I (337-352) and Damasus. ${ }^{28}$ After the fire of 1823 in St Paul's, 41 images survived but they are preponderantly late and repainted. However, the series from St Peter to Urban I (222-230) reveal fifth-century style and there is evidence that Pope Leo I may have inaugurated this series of papal images in the basilica. The later popes were apparently painted in the Middle Ages. ${ }^{29}$ There were papal images in Old St Peter's too but descriptions of them made before the building was demolished are too imprecise to say whether they were late antique or medieval. Thinking about imperial and consular images provides an opportunity to imagine the significance of popes placing their own images in public places. The scale of these phenomena are of course vastly different. Still, images, like inscriptions, create durable reminders of papal presence. In MacMullen's terms they speak to the present and to the future.

The remote origins of Rome's stational liturgy may reach back as far as the second century, but the well-developed system that we find in Ordo Romanus Primus, which dates from around 700, took shape only in the fifth and sixth centuries. ${ }^{30}$ Gradually stately processions that were designed for the Lenten season expanded to the whole of the liturgical year. The popes and a number of their high officials, preceded by crosses and banners, garbed in luxurious vestments, and bearing books, liturgical vessels, and relics processed across the city from one neighborhood to another. Leo I provided a full set of vessels for the stations. ${ }^{31}$ Doubtless other popes added to the collection. These impressive processions communicated both authority and prestige. They bore a certain similarity to both military triumphs and official adventus. When I think of a stational procession I am reminded of Ammianus's colorful description of Constantius II parading through Rome - but not of the historian's wicked criticism. ${ }^{32}$ Be that as it may, Rome saw little imperial pomp after the middle

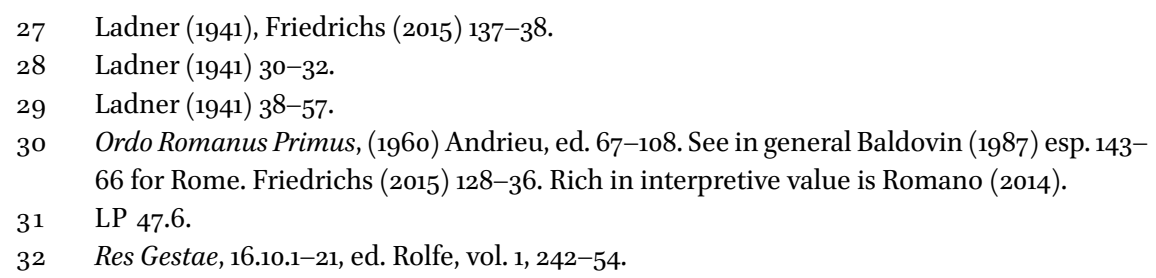


of the fourth century so when the papal stations began to develop they represented the only game in town, so to speak. No one else, secular or clerical, put himself and in some sense his office on display the way Rome's bishops did. ${ }^{33}$ And they did it routinely. At the stations, moreover, the popes preached. We have ninety-six surviving sermons from Pope Leo I (440-461) and we know in almost all cases the days on which they were preached. ${ }^{34}$ The Liber Pontificalis says that Gregory I produced forty homilies on the Gospels, thirty-five on Job, and twenty on Ezekiel. ${ }^{35}$ In many cases we do not know exactly when these were preached but we do have, from the year 591, a sequence of sermons delivered from April 15 to April 22 at Santa Maria Maggiore, St Peter's, San Lorenzo, and then three at the Lateran. ${ }^{36}$ All the popes must have preached and it is only an accident of survival that we have today so few of their sermons. Speaking before an assembly of one's fellow Romans was both a privilege and an opportunity from the earliest days of the Republic. Speaking in one after another of Rome's great basilicas was not so very different from erecting signed messages or placing images in those buildings albeit the force of a sermon was evanescent.

Between 314 and 715 popes presided over 39 councils in Rome. ${ }^{37}$ There was a council about every ten years on average. Of the $5^{6}$ popes who reigned in these years 31 held no councils, as far as we know, while 25 did hold at least one. Damasus held 6. In 20 cases we do not know how many bishops attended or where they came from. In 19 cases we do know how many bishops attended and in some cases we have lists of signatories. The number of attendees ranged from a low of 5 to a high of 105 . The average number of attendees was about 45 . The overall list reveals some anomalies. There were no councils between $53^{1}$ and 595. These were of course extremely difficult years for Italy, marked by the Gothic Wars and then the Lombard incursion. The absence of synodal activity in these years runs parallel to a sharp decline in the number of papal letters. Only 167 letters survive from these years and 99 of them come from Pelagius I (556-561). One has the impression that ecclesiastical business ground nearly to a halt. Still, of the eight popes who reigned during this synodal gap, five of them installed inscriptions. With the decline and eventual disappearance

33 I am sensitive to the fact that Humphries (2007) argues for a more persistent and important imperial presence in the city.

34 Leo I, Sermones (1973), Chavasse ed.

$35 \quad$ LP 66.1.

36 Jaffé (1885) vol. 1,147-48.

37 The following tabulations are based on Jaffé (1885). The conciliar records may be found in Mansi, ed. (1759-65), vols. 3-12. The synods held under Symmachus are published in Mommsen (1894), 393-455. 
of Rome's secular institutions, papal synods looked like the only deliberative assemblies in the city. The majority of attendees would have come from Italia suburbicaria and their pretty regular appearance with each other and with the popes will have been a significant enhancement and public representation of papal authority. One suspects that the population of the city grew quite accustomed to having visiting ecclesiastical dignitaries in their midst.

Last I come to the construction, renovation, and decoration of Roman churches within and without the city. ${ }^{38}$ Of the 56 popes under consideration here, 40 built or renovated churches and/or made significant donations to them. A total of 75 churches were built or renovated, 30 in the city and 45 outside. Eighteen churches received donations, 10 in the city and 8 outside. These numbers permit some closer analysis. Between 530 and 555 the Liber Pontificalis records no construction, renovation, or donation with the single exception of Agapitus's installation of a library in the monastery on the Clivus Scauri. Things are then pretty grim again until the pontificate of Pelagius II (579-590) who built the great basilica of San Lorenzo, as well as a church at the cemetery of Hermes, and he made some donations. But for the period between 555 and 579 we hear only that Pelagius I began the basilica of Philip and James, or Santi Apostoli, and that John III completed it. We have noticed this same gap before. Every church in the city that has a surviving inscription was also the beneficiary of construction or renovation. Of the 21 churches outside the city that had inscriptions 8 do not preserve evidence of construction or renovation but these are all cemeterial churches and 8 cemeterial churches with inscriptions do in fact show construction. Given this close correlation between construction work and surviving inscriptions, and given that the number of churches with inscriptions represents about $43 \%$ of all the churches that reveal construction, I am led to think that we have lost a great many inscriptions. The donation records are mostly pretty straight forward. Liturgical vessels and light fixtures make up the preponderance of items donated by the popes to Rome's churches although we do hear of mosaics. Leo I, the Liber Pontificalis says, made significant donations of liturgical paraphernalia because of the "Vandal disaster" (cladem Wandalicam). ${ }^{39}$ Yet we have no such report for Innocent I who was pope when the Visigoths forced their way into the city in 410. Innocent's vita does contain one particularly interesting fact. 'A certain illustrious woman Vespina' willed that enough of her jewels should be sold to finance the construction of a basilica in honor of Gervasius and

38 The following tabulations are based on the LP. And see above n. 18 .

$39 \quad$ LP 47.6. 
Protasius. ${ }^{40}$ Innocent himself then made generous donations to that basilica. A Goth named Valila endowed the church of Sant'Andrea in Catabarbara that Simplicius built, apparently in the $470 .^{41}$ I wonder how many bequests like Vespina's and Valila's stand behind other papal construction or donation projects. ${ }^{42}$ Moreover, these generous acts show that the popes' relations with local notables were not always contentious. ${ }^{43}$

For yet another time, then, we can see the popes putting their mark on Rome and its suburbs consistently and over a long period of time. The third century had seen the nadir of construction in Rome. Things picked up in the fourth and subsequent centuries, albeit the sixth and seventh centuries were a bit jejune. Yet now the church, indeed the papacy, was the party most responsible for the work. It is true that the three great basilicas of St Peter's, St Paul's, and the Lateran were imperial projects. Still, these three basilicas saw at least 28 papal construction or renovation projects and around 25 papal donations. Rome's populace can hardly have been blind to the fact that the popes were constantly improving the city-scape and putting a lot of people to work. That is patronage on a pretty massive scale. I do not know how many people like Vespina and Valila stood behind the papal projects but it does seem clear that the wealthy and influential no longer directed their evergetism to secular monuments. I suggested earlier that some at least of the papal attention to Rome's suburbs might have had a material dimension. The construction and donation records betray the expenditure of a lot of money and I am confident that a lot of that money was generated in the agro Romano. Finally, the very fact that papal officials retained the extraordinary records of construction, renovation, and donation that we now read in the pages of the Liber Pontificalis urges us to think that memorialization of papal activity was as high a priority as the activity itself.

Inscriptions, to close the circle, are a key form of memorialization too. Let me now turn to some of the most important things the papal inscriptions actually say. The series of inscriptions begins with Damasus. He placed inscriptions at both major churches and at the cemeteries and tombs of saints and martyrs. I am not aware of any earlier pope drawing attention to these sites. Damasus placed his commemorative poetic inscriptions, usually crafted in the beautiful

\footnotetext{
$40 \quad$ LP 42.3 .

41 A detail preserved in the dedication inscription found in LP 1.250 (CLE 916.1-10).

42 Hillner (2007) 225-32. In the same volume see Cooper 165-89 and Kurdock 190-224.

43 See above for the possibility that collaboration may have been as prominent as contention (p. 63).
} 
Philocalian script, at the following places (I include the ones that are legible and omit the small fragments): ${ }^{44}$

\begin{tabular}{|c|c|}
\hline \multirow{3}{*}{$\begin{array}{l}\text { Cemetery of Commodilla } \\
\text { Cemetery of San Callisto }\end{array}$} & Felix and Adauctus \\
\hline & Tarsicius, various Saints, Pope Sixtus II, \\
\hline & Pope Eusebius, Pope Cornelius \\
\hline San Sebastiano & Peter and Paul, Eutychius \\
\hline Cemetery of Praetextatus & $\begin{array}{l}\text { Januarius, Felicissimus and Agapitus, } \\
\text { Quirinus(?) }\end{array}$ \\
\hline Cemetery ad duas lauras & $\begin{array}{l}\text { Marcellinus and Peter, Tiburtius, } \\
\text { Gorgonius }\end{array}$ \\
\hline Cemetery of Ager Veranus & \\
\hline (=San Lorenzo) & Lawrence \\
\hline Cemetery of Hippolytus & Hippolytus \\
\hline Cemetery of Sant'Agnese & Agnes \\
\hline Cemetery of Priscilla & Felix and Philippus, Pope Marcellus \\
\hline Cemetery of the Jordani & Alexander \\
\hline Cemetery of Traso (= Church of & Maurus, Chrysanthus and Daria, \\
\hline Chrysanthus and Daria) & J : i t \\
\hline emetery of Basilla at St Herr & Protus and Hyacinthus, Hermes \\
\hline
\end{tabular}

Damasus mounted a few more inscriptions that will capture our attention later. His successors often continued the practice. Boniface commemorated Felicity at her cemetery; ${ }^{45}$ Sixtus III celebrated Peter and Paul at San Pietro in Vincoli; ${ }^{46}$ Simplicius fêted Andrew at Sant'Andrea in Catabarbara; ${ }^{47}$ Symmachus commemorated Protus and Hyacinth and also St Andrew at the Vatican Rotunda; ${ }^{48}$ Felix IV dedicated an apsed hall flanking Vespasian's Forum of Peace to Santi Cosma e Damiano (called only "the martyred physicians" in the inscription); ${ }^{49}$ Pelagius I began and John III completed a church dedicated to Philip and

44 All are edited and beautifully translated in Trout (2015). I prefer this edition to the older one of Ferrua (1942). In every instance Trout references Ferrua for the convenience of those who have long used that edition. I quote Trout's translations throughout.

45 LP 1.229. ICUR 8, no. 23394. I did not have continuous access to all volumes of ICUR so I default to the texts published in LP and supply ICUR numbers when I have them.

46 CLE 912.3: Latin Inscriptions (2009) Lansford ed. 104-5.

$47 \quad$ LP 1.250; ICUR 2, no. 4106.

48 LP 1.265-66.

49 Ibid. 280. 
James; the latter installed an inscription; ${ }^{50}$ Pelagius II honored Lawrence at San Lorenzo; ${ }^{51}$ John IV honored the dedicatee at San Venanzio; ${ }^{52}$ as did Theodore at Santo Stefano Rotondo. ${ }^{53}$ A few of these were of course inside the city - Sant'Andrea in Catabarbara, San Pietro in Vincoli, Santo Stefano Rotondo, and San Venanzio. There is no obvious pattern in these dedications and commemorations.

I will come back to one or two of these commemorations later but for now it can be said that, in general terms, the words of the inscriptions are something like holy boilerplate. They may or may not say something about the circumstances of a particular saint's martyrdom but usually the inscription merely asks the viewer to be mindful that he or she is in the presence of saint soand-so. Sometimes the inscribing pope invites the viewer to request the saint's intercession and sometimes the pope asks the saint himself or herself to intercede for him. In almost all cases the inscription tells the viewer that a specific pope has drawn attention to this or that saint. That is what strikes me as interesting about them. The popes more or less ostentatiously named themselves as the founder or patron or promoter of a saint's cult.

In a few cases popes used inscriptions to call attention to theological struggles and they portray themselves as defenders of the one true faith. The celebration of the Council of Ephesus in $43^{2}$ by Sixtus III at his new basilica that we know as Santa Maria Maggiore is well known. The images on the triumphal arch have been the subject of many studies. ${ }^{54}$ Less well known, perhaps, is the inscription that once stood above the front door. There Sixtus wrote 'Virgin Mary, to you, I, Sixtus, dedicate this new building / worthy gifts to your saving womb.' There was also an image with two processions of martyrs who were witnesses to the fruit of Mary's saving womb and Sixtus goes on saying that Mary was pregnant though she knew not man and gave birth with an intact womb. ${ }^{55}$ The Ephesan doctrine of the Theotokos was clearly emphasized here. In San Pietro in Vincoli Sixtus celebrated a certain Philip who was Celestine's representative at Ephesus where "Christ triumphed for East and West"56 In his famous inscription in the Lateran baptistery Sixtus says 'By a virgin birth Mother Church (Genetrix ecclesia) brings forth children' - another reference to

5o Ibid., 306; ILCV 1766a-b with ILCV 1767.

$5^{1}$ Ibid., 310; second inscription quoted is ICUR 7.18371.

$5^{2}$ Ibid., 330; ILCV 1786a.

53 Ibid., 334.

54 The classic remains Brenk (1975).

$55 \quad$ LP 1.235; ILCV 976.

56 CLE 912.7-8; Latin Inscriptions (2009) Lansford, ed., 104 (Latin), 105 (English). 
Ephesus. ${ }^{57}$ Silverius prepared an epitaph for Pope Hormisdas at St Peter's. I have not otherwise included papal epitaphs for reasons I mentioned earlier. But this one is especially interesting because Silverius says that Hormisdas, 'Captured by the love of Peter ... you healed the body of the fatherland that had been slashed by schism. ${ }^{58}$ The reference of course is to Hormisdas's successful conclusion to the Acacian Schism that had separated Rome and Constantinople for decades. There is, I think, a veiled reference to theological contention in Agapitus's inscription for the library he installed in the monastery on the Clivus Scauri. Addressing the books to be placed in the library Agapitus says 'Equal is our thanks to all of them for there was a single holy labor for them all. Their words to be sure were different but there was only one faith. ${ }^{59}$ Finally, on the altar of San Lorenzo Pelagius II says that God came down to earth to teach his disciples what they in turn should teach. The faithful people offer these gifts, that is the basilica and its furnishings, so that the Roman scepters would be wielded with a celestial hand and the true faith might be free ${ }^{60}$ If I am not mistaken this is a reference to the Second Council of Constantinople in 553, its condemnation of the Three Chapters at the behest of Justinian I, and the strife that followed that council. ${ }^{61}$ The Three Chapters controversy echoed down through the seventh century and Honorius mounted an inscription at the entrance to St Peter's that begins by paraphrasing that of Pelagius II and then goes on to address the schismatic situation in Istria. ${ }^{62}$ Again, the pope defends the true faith.

Finally, I come to the most persistent and interesting set of themes that recur constantly in the papal inscriptions. In different ways the texts celebrate the popes and the papacy, St Peter, the apostolic office, and a particular kind of Roman Christian identity. These inscriptions add both breadth and depth to the kinds of arguments that scholars have long drawn from sources such as papal letters and the Liber Pontificalis. Ordinary Roman people never saw a papal letter and never read the Liber Pontificalis but they could not have avoided seeing the visible and prominent assertions made in the inscriptions.

Among the persons whom they commemorated, popes took a notable interest in their predecessors. Damasus erected a baptistery at St Peter's and memorialized his famous predecessor. At San Callisto Damasus mentioned by

\footnotetext{
57 Ibid., 232 (ILCV 1513.7-8): Virgineo fetu genetrix ecclesia natos / quos spirante Deo concipit amne parit.

58 LP 1.274; ICUR 2, no. 1450.

59 Ibid., 288; CLE 1842.

6o Ibid., p. 310; ICUR 2, no. 4117.

61 On all of these issues see most recently Chazelle and Cubitt (2007). I do no recall that any author included in the volume mentioned Agapitus's inscription.

62 LP 1.325; ICUR 2, no. 4119. See Scholz (2016) 128-30.
} 
name Sixtus II in two different elogia and this was a place whose crypt held the bodies of nine third-century popes. ${ }^{63}$ In the same place he mounted an elogium to Pope Eusebius. Likewise a badly damaged tablet appears to commemorate Damasus' work in facilitating access to the tomb of Pope Cornelius. At San Sebastiano Damasus put up an inscription saying that Peter and Paul had once been buried there. His elogium to Felicissimus and Agapitus at the cemetery of Praetextatus mentions their bishop Sixtus whose faith the saints had imitated. Similarly he celebrated Pope Marcellus, who had bravely withstood the attack of Maxentius, at the cemetery of Priscilla. Along the Via Flaminia Damasus memorialized a Marcus that some scholars have taken to be Pope Marcus who reigned briefly in $336 .{ }^{64}$ The inscription in Santa Sabina memorializing the church's foundation mentions Pope Celestine. ${ }^{65}$ Sixtus III blessed the church of San Pietro in Vincoli in the name of Peter and Paul together. ${ }^{66} \mathrm{He}$ also placed a slab at San Callisto bearing the names of twenty popes. ${ }^{67}$ Galla Placidia set an inscription in St Paul's thanking 'Pontiff Leo' for renewing her father's work. ${ }^{68}$ Symmachus dedicated an oratory at St Peter's to Andrew "the brother of Peter who suffered dreadfully" 69 The work was completed by Pope John (II) Iohannes hoc composuit opus who added an inscription saying "Peter, gatekeeper of eternity, crowns the porticus." ${ }^{\text {"70 }}$ Silverius, as I already noted, commemorated Hormisdas who healed the Acacian schism because of his love for Peter. In his altar inscription at San Lorenzo Pelagius II says that the faith had been preserved "by the power of Peter." ${ }^{\text {"11 }}$ Finally, Sergius moved the tomb of Leo I into St Peter's because it had been obscured by surrounding monuments. ${ }^{72}$ Taken together I think these commemorations constitute impressive testimony to a sense of personal and official succession. One important dimension of office is official continuity.

I have mentioned commemorations of Peter several times. In the inscription for his new baptistery at St Peter's Damasus calls Peter 'his surety' and 'the gatekeeper of heaven.' He says, further, that 'as there is one see of Peter so there is one baptism.' And Damasus calls himself antistes Christi. Damasus'

\footnotetext{
63 Webb (2001) 231; Borgolte (1989) 21-24.

64 All in Trout (2015).

65 CLE 312; Lansford (2009), 168: Culmen apostolicum cum Caelestinus haberet.

66 CLE 912.3; Latin Inscriptions (2009) Lansford ed., 104: haec Petri Paulique simul nunc nomine signo / Xystus apostolicae sedis honore fruens.

$67 \quad$ LP 1.236.

68 Latin Inscriptions (2009) Lansford ed., 182.

69 LP 1.265-66; ICUR 2, no. 1426.

$70 \quad$ Ibid. 267; ICUR 2, no. 4116.

71 Ibid. 310; ICUR, 2, no. 4117.

72 Ibid. 379; ICUR 2, no. 4148.
} 
inscription at his titulus of San Lorenzo in Damaso thanks Christ who 'wished to grant to me the honor of the apostolic see. ${ }^{73}$ At Santa Sabina Celestine 'possessed the apostolic preeminence and shone forth as the first bishop in all the world. ${ }^{74}$ As Erik Thunø notes the huge and beautiful inscription on the end wall of Santa Sabina has the word PETRUS right in its middle. This example confirms his point that inscriptions had both textual and visual dimensions. ${ }^{75}$ At San Pietro in Vincoli Sixtus III says 'I, Sixtus, who enjoys the honor of the apostolic see. ${ }^{76}$ The Symmachan oratories at the Lateran were completed by John II quem rite coronat Urbis Romanae pontificalis apex. ${ }^{77}$ And as I noted, 'Peter, the gate keeper of heaven, crowns the porticus'. In San Pietro in Vincoli John was 'raised to the pontifical glory' and so he made an offering to 'the blessed apostle Peter, his patron.78 Pelagius, again, attributed the preservation of the faith to 'the power of Peter (Petrivirtute). ${ }^{79}$ In his chapel of the martyrs in Santo Stefano Rotondo we read pastoris summi Theodori. ${ }^{80}$ And, last, Sergius moved the tomb of Leo I to 'where the final glory of the pontiff will be greater.'81 For three centuries popes connected themselves to Peter, heaven's guardian. They were his successors. They held, his, the apostolic office. They were the world's first bishop and highest pastor. ${ }^{82}$

In a closely related theme we can see the popes placing themselves, and being placed, at the head of a particular kind of community. I have already signaled the intimate relationship that popes claimed with Rome's martyrs. This suggests a kind of bond between Rome's living and dead, a kind of celestial society whose earthly head was the pope. Damasus says that the 'glory of the Roman people rejoices in the saints.' ${ }^{83}$ Who are those people? The Romans, to be sure, but a very special kind of Romans. On three occasions Damasus mentioned martyrs who came to Rome, died there, and became "citizens": Peter and Paul, St Saturninus, and St Hermes. ${ }^{84}$ Of what polity were they citizens? On the triumphal arch of Santa Maria Maggiore we can still read

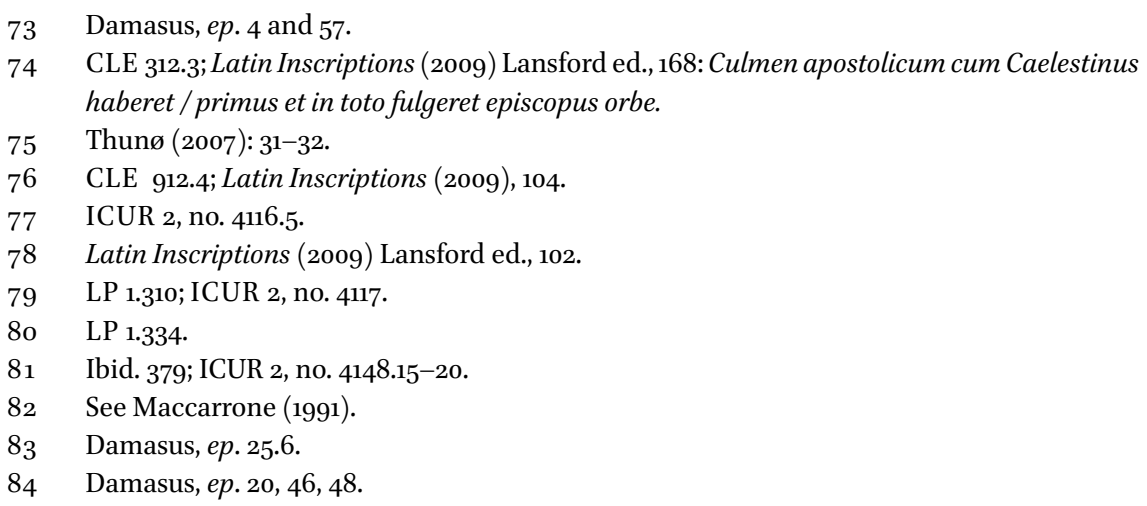


XYSTUS EPISCOPUS PLEBEI DEI, 'Sixtus bishop for the people of God'.85 Richard Krautheimer observed that this phrase has a flavor both Biblical and classical: ${ }^{86}$ Indeed, it does, not least in its use of PLEBI instead of POPULO. In Republican times plebs referred to the common people, not to the Roman people as a whole. In late Latin the words were synonymous. ${ }^{87}$ I think that Sixtus's use of plebs was a deliberate, ideologically inflected anachronism. I heartily agree with Marianne Sághy who speaks of Damasus's 'creative recycling of Romanitas'. She goes on to say that the bishop 'sought to anchor his Church and his authority in distinctly Roman 'patriotic' traditions' doing so in part by means of a 'sophisticated and subversive referencing of the past' 88

Damasus was not alone in doing all this. In the oratory of St John the Baptist at the Lateran we find HILARIUS EPISCOPUS SANCTAE PLEBEI DEI, Bishop Hilary for the holy people of God. ${ }^{89}$ Note how Damasus's 'people' have become Hilary's 'holy people'. As noted already, Theodore called himself pastor summus. Surely this was the populace within which the martyrs had become citizens and of which the pope was the highest pastor. These are the people referenced in the first line of Sixtus III's inscription in the Lateran baptistery: 'Here from a fostering seed is born a people to be consecrated to heaven.' A few lines further on Sixtus wrote 'By a virgin birth Mother Church brings forth in the river / the children whom she conceives by the breath of God'. ${ }^{90}$ The people of God, the Roman citizens, were the children of Mother Church. But before Sixtus, Damasus had already said this in dramatic, expressive language. In recounting the savage deaths of the martyrs Damasus five times used the phrase tempore quo gladius secuit pia viscera matris - 'in the days when the sword hacked at the holy guts of our mother'.91 Mother here can only mean the church, the holy people, the people intended for heaven, the people whose pastor was the apostolic, the heir of Peter.

In conclusion, I have tried to show how by papal images, liturgical processions, synodal meetings, and by the building, renovating, and decorating of churches the popes put their stamp on Rome and its environs in similar ways over the four centuries following the Constantinian peace of the church. Then I tried to show how the papal inscriptions, by their very existence and location,

85 ILCV 975; LP 1.235. The inscriptions that I print in capitals are found in majuscules. Editions usually reproduce them in capitals.

$86 \quad$ Krautheimer (1980) 49.

87 Lewis and Short (1879) 1386, s.v. plebs.

88 Sághy (2016) 314.

89 LP 1.245.

90 Latin Inscriptions. (2009) Lansford ed., 232 (I cite his translation from 233).

$91 \quad$ Damasus, ep. 17.1, 31.1, 35.3, 43.1 and 46.3. 
and by what they actually say, did much the same thing albeit more explicitly, although no less consistently. The inscriptions have been primarily the preserve of technically proficient epigraphers and of literary scholars who study Latin Christian poetry. They have almost never been brought into discussions of the "rise of the papacy" and that rise is in reality the agenda behind my study. In recent decades some scholars have queried the rise of the papacy. ${ }^{92}$ I share their concerns but not their conclusions. Leaving aside the work of the truly great nineteenth- and twentieth-century scholars, I think that most of the skeptics have aimed their interpretative weapons at the work of Walter Ullmann. Like them, I too am skeptical about the vast claims that Ullmann made for The Growth of Papal Government. Papal government, understood as institutions, did in fact begin emerging as early as the fourth century. The evidence for those institutions cannot be dismissed out of hand. But papal government grew slowly, awkwardly, and all too often in ways that later evidence makes very difficult to trace back coherently into late antiquity. It is well and good to issue dire warnings about teleology. But the papacy is the world's oldest continuously functioning institution. It did grow and the seeds of its growth were planted in late antiquity. What people really object to in Ullmann's approach is his insistence that abstract claims to authority and power, usually expressed in ideological and ecclesiological terms, had any real purchase on the late antique world. It is easy to show that papal claims often went unheeded and it is an incontrovertible fact that late antique popes lacked the coercive tools necessary to make good on their grander claims.

But my claim is different. I find no Nicholas I, or Gregory VII, or Innocent III, or Boniface VIII, or Pius IX in late antiquity. Instead, I am claiming that, as a famous American politician once said, 'All politics are local'. Between the fourth century and the early eighth the popes built a distinctive local community over which they claimed authority on the basis of apostolic succession, pastoral office, and official continuity. I concede that the popes struggled at times to make their authority good in their own locality. George Demacopoulos argues that popes made claims primarily in times of crisis. He is only partly right about that, for he overlooks that claims, in the very broad sense in which I have tried to treat claims, were not exclusive to times of crisis. What is more, times of crisis can be generative of both dynamic claims and decisive actions. I have tried to show that claims and actions ran parallel, were articulated in concrete and not in abstract terms, and proved to be of lasting significance. If the papacy did not "rise" in late antiquity, then when did it rise? 


\section{Bibliography of Primary Sources}

Acta Synhodorum habitarum Romae a CCCCXCVIIII, DI, DII, 1894. Mommsen, T. ed., MGH, Auctores Antiquissimi, vol. 12, pp. 393-455. Berlin: Weidmann.

Ammianus Marcellinus, 1972. Rerum Gestarum Libri Qui Supersunt. Rolfe, J. C. ed. Cambridge, MA: Harvard University Press.

Codice topografico della città di Roma. 1940-43. 4 vols., Valentini, R. and Zuchetti, G. eds. Fonti per la storia d'Italia 81, 88, 90, 91. Roma: Tipografia del Senato.

Epigrammata Damasiana. 1942. Ferrua, A. ed. Città del Vaticano: Pontificio Istituto di Archaeologia Cristiana.

Inscriptiones Christianae Urbis Romae, 1935-83. Vols. 2, 7, 8. Salvagni, A. and Ferrua, A. eds. Città del Vaticano: Pontificio Istituto di Archaeologia Christiana.

The Latin Inscriptions of Rome. 2009. Lansford, T. ed. and trans. Baltimore: Johns Hopkins University Press.

Le Liber Pontificalis. Repr. 1981. 2nd ed. 1955. Duchesne, L. ed. 2 vols. Paris: Éditions de Boccard.

Leo I 1973. Sermones Chavasse, A. ed. Corpus Christianorum Latinorum 138, 138a. Turnhout: Brepols.

Ordo Romanus Primus. 196o. Andrieu, M. ed. Les Ordines Romani du haut moyen age, vol. 2, Les textes 67-108. Spicilegium Sacrum Lovaniense 23. Louvain: Spicilegium.

Petrus Mallius 1946. Descriptio Basilicae Vaticanae aucta atque emendata a Romano presbyterio, Valentini, R. and Zucchetti, G., eds. In Codice topografico della città di Roma, vol. 9o, pp. 375-442. Roma: Tipografia del Senato.

Sacrorum Conciliorum Nova et Amplissima Collectio. Vols. 3-12. 1759-65. Mansi, G. D. ed., Florence; repr. Leipzig: Geidel, 1901.

\section{Bibliography of Secondary Sources}

Azzara, C. 1997. L'ideologia del poetere regionale nel papato altomedievale (secoli VIVIII). Testi, Studi, Strumenti 12. Spoleto: Centro Italiano.

Baldovin, J. S. J. 1987. S. J., The Urban Character of Christian Worship: The Origins, Development, and Meaning of Stational Liturgy. Roma: Pontificum Institutum Studiorum Orientalium.

Birch, D. J. 1998. Pilgrimage to Rome in the Middle Ages. Studies in the History of Religion 13. Woodbridge: Boydell.

Brenk, B. 1975. Die frühchristlichen Mosaiken in Santa Maria Maggiore zu Rom. Wiesbaden: Steiner.

Caspar, E. 1930. Geschichte des Papsttums von den Anfängen bis zur Höhe der Weltherrschaft, vol. 1. Tübingen: J. C. B. Mohr. 
Chazelle, C. M. \& C. Cubitt, eds. 2007. The Crisis of the Oikumene: The Three Chapters and the Failed Quest for Unity in the Sixth-Century Mediterranean. Turnhout: Brepols.

Cooper, K. \& J. Hillner, eds. 2007. Religion, Dynasty, and Patronage in Early Christian Rome, 300-90o. Oxford: Oxford University Press.

Cooper, K. 2007. Poverty, Obligation, and Inheritance: Roman Heiresses and the Varieties of Senatorial Christianity in Fifth-Century Rome. In Cooper \& Hillner (2007) $165^{-89}$.

Costambeys, M. 2000. Property, Ideology and the Territorial Power of the Papacy in the Early Middle Ages. Early Medieval Europe 9: 367-96.

Curran, J. Pagan City and Christian Capital: Rome in the Fourth Century. Oxford: Oxford University Press.

De Blaauw, S. 1994. Cultus et Décor: Liturgia e Architettura nella Roma Tardoantica e Medioevale, 2 vols. Città del Vaticano: Biblioteca Apostolica Vaticana.

Demacopoulos, G. 2013. The Invention of Peter: Apostolic Discourse and Papal Authority in Late Antiquity. Philadelphia: University of Pennsylvania Press.

Dey, H. 2008. Diaconiae, Xenodochia, Hospitalia and Monasteries: 'Social Security' and the Meaning of Monasticism in Early Medieval Rome. Early Medieval Europe, 16.4: 398-422.

D’Onofrio, M. ed. 2016. La commitenza artistica dei papi nel medioevo. Roma: Viella.

Dunn, G. D. ed. 2015. The Bishop of Rome in Late Antiquity. London: Routledge.

Ferrua, A. 1939. Filocalo, l'amante della bella lettera, La Civiltá Cattolica, 90: 35-47.

Foletti, I. \& Manuela Gianandrea, eds. 2017. The Fifth Century in Rome: Art, Liturgy, Patronage. Roma: Viella.

Friedrichs, K. 2015. Episcopus Plebi Dei: Die Repräsentation der frühchristlichen Päpste. Regensburg: Schnell \& Steiner.

Gianandrea, M. 2017. The Artistic Patronage of the Popes in Fifth-Century Rome. In Foletti and Gianandrea (2017) 183-216.

Gianandrea, M. 2016. Il V secolo: da Innocenzo I (401-417) ad Anastasio II (496-498). In D’Onofrio (2016) 73-108.

Gray, N. 1956. The Filocalian Letter. PBSR 24: $5^{-13}$.

Grig, L. \& G. Kelly, eds. 2012. Two Romes: Rome and Constantinople in Late Antiquity. Oxford: Oxford University Press.

Guiglia, A. 2016. Il VI secolo: da Simmaco (498-514) a Gregorio Magno (590-604). In D'Onofrio (2016) 109-143.

Guyon, J. 1987. Le cimitière des deux lauriers: Recherches sur les catacombs romaines. Roma: École française de Rome.

Halphen, L. 1907. Études sur l'administration de Rome au Moyen Age. Paris: Honoré Champion.

Handley, M. A. 2003. Death, Society and Culture: Inscriptions and Epitaphs in Gaul and Spain, $A D$ 300-750. Oxford: Archaeo Press. 
Hillner, J. 2007. Families, Patronage, and the Titular Churches of Rome. In Cooper \& Hillner (2007) 225-61.

Hornung, C. 2015. Siricius and the Rise of the Papacy In Dunn (2015) 57-72.

Humphries, M. 2012. Valentinian III and the City of Rome (425-455): Patronage, Politics, Power. In Grig \& Kelly (2012) 161-82.

Humphries, M. 2007 From Emperor to Pope? Ceremonial, Space, and Authority at Rome from Constantine to Gregory the Great. In Cooper \& Hillner (2007) 21-58.

Jaffé, P. 1885. Regesta Pontificum Romanorum, vol. 1, 2nd ed. Leipzig: Veit.

Kinney, D. 2017. Expanding the Christian Footprint: Church Building in the City and the Suburbium. In Foletti \& Gianandrea (2017) 65-97.

Klauser, T. 1972. Rom und der Kult der Gottesmutter Maria.JbAC 15: 120-35.

Krautheimer, R. 1980. Rome: Profile of a City, 312-1308. Princeton: Princeton University Press.

Kurdock, A. 2007. Demetrias Ancilla Dei: Anicia Demetrias and the Problem of the Missing Patron. In Cooper \& Hillner (2007) 190-224.

Ladner, G. B. 1941. Die Papstbildnisse des Altertum und des Mittelalters, vol. 1 Bis zum Ende des Investiturstreits. Città del Vaticano: Pontificio Istituto di Archeologia Cristiana.

Lewis, C. T. \& C. Short. 1879. A Latin Dictionary. Oxford: Clarendon Press.

Lucherini, V. 2016. Il IV secolo: da Silvestro I (314-335) ad Anastasio I (399-401). In D’Onofrio (2016) 51-72.

Maccarrone, M. ed. 1991. Il primato del vescovo di Roma nel primo millennio: Ricerche e testimonianze. Città del Vaticano: Libreria Editrice Vaticana.

Maccarrone, M. 1991a. Sedes Apostolica - Vicarius Pietri: Le perpetuità del primato di Pietro nella sede e nel vescovo di Roma (Secoli III-VIII). In Maccarrone (1991) $275^{-362 .}$

Machado, C. 2012. Aristocratic Houses and the Making of Late Antique Rome and Constantinople. In Grig \& Kelly (2012) 136-58.

MacMullen, R. 1982. The Epigraphic Habit in the Roman Empire. AJPh 103.3: 233-46.

Marazzi, F. 1998. I 'Patrimonia Sanctae Romanae Ecclesiae' nel Lazio (secoli IV-X): Struttura amministrativa e prassi gestionali. Roma: Sede dell'Istituto.

Meyer, E. 1990. Explaining the Epigraphic Habit in the Roman Empire: The Evidence of Epitaphs. JRS 80: 74-96.

Moorhead, J. 2015. The Popes and the Church of Rome in Late Antiquity. London: Routledge.

Moreau, D. 2006. Les patrimoines de l'Église romaine jusqu'à la mort de Grégoire le Grand: Dépouillement et reflexions préliminaires sur le role temporel des èvêques de Rome durant l'antiquité le plus tardive. L'Antiquité tardive: 79-93.

Noble, T. 2013. The Reception of Visitors in Early Medieval Rome. In Discovery and Distinction in the Early Middle Ages: Studies in Honor of John J. Contreni. 
Ed. C. Chandler \& S. A. Stofferahn, 205-17. Kalamazoo: Medieval Institute Publications.

Noble, T. 2000. Paradoxes and Possibilities in the Sources for Roman Society in the Early Middle Ages. In Smith, J. M. H. ed., Early Medieval Rome and the Christian West: Essays in Honour of Donald A. Bullough, 58-73. Leiden: Brill.

Petrucci, A. 1998. Writing the Dead:Death and Writing Strategies in the Western Tradition. Stanford: Stanford University Press.

Pietri, C. 1991. La conversion de Rome et la primauté du pape (IV-VI siècle). In Maccarrone (1991a) 219-43.

Pietri, C. 1976. Roma Christiana: Recherches sur l'Église de Rome, son organisation, sa politique, son idéologie de Miltiade à Sixte III (311-440), Bibliothèque des Écoles françaises d'Athènes et de Rome 280. Roma: École française de Rome.

Ramsby, T. R. 2007. Textual Permanence: Roman Elegists and the Epigraphic Tradition. London: Duckworth.

Romano, J. F. Liturgy and Society in Early Medieval Rome. Farnham: Ashgate.

Rubin, M. 2009. Mother of God:A History of the Virgin Mary. New Haven: Yale University Press.

Sághy, M. 2016. Romanae Gloria Plebis: Bishop Damasus and the Traditions of Rome. In Salzman, M. R., Sághy, M. \& R. L. Testa, eds., Pagans and Christians in Late Antique Rome: Conflict, Competition, and Coexistence in the Fourth Century 314-27. Cambridge: Cambridge University Press.

Sághy, M. 2015. The Bishop of Rome and the Martyrs. In Dunn (2015) 37-56.

Sághy, M. 2000. Scinditur in partes populous: Pope Damasus and the Martyrs of Rome. Early Medieval Europe 9: 273-87.

Saxer, V. 2001. La chiesa di Roma dal V al X secolo: Amministrazione centrale e organizzazione territoriale. In Roma nell'alto medioevo, 493-632. Settimane di Studio del Centro Italiano di Studi sull'alto Medioevo 48. Spoleto: Sede del Centro.

Saxer, V. 1984. Damase et le calendrier des fêtes des martyres de l'Église romaine. In Saecularia Damasiana: Atti del convegno internazionale per il XVI centenario della morte di Papa Damaso, 59-88. Città del Vaticano: Pontificio Istituto di Archeologia.

Schneidmüller, B. ed. 2016. Die Päpste: Amt und Herrschaft in Antike, Mittelalter und Renaissance, Die Päpste 1. Regensburg: Schnell \& Steiner.

Scholz, S. 2016. Primat und päpstlichen Politik in den römischen Inschriften von der Spätantike bis ins hohe Mittelalter. In Schneidmüller (2016) 121-35.

Sessa, K. 2012. The Formation of Papal Authority in Late Antique Italy: Roman Bishops and the Domestic Sphere. Cambridge: Cambridge University Press.

Taddei, A. 2016. Il VII secolo: da Sabiniano (604-606) a Sergio I (687-701). In D’Onofrio (2016) $145^{-180 .}$

Thompson, G. 2015. The Pax Constantina and the Roman Episcopate. In Dunn (2015) $17-36$. 
Thunø, E. 2007. Looking at Letters: Living Writing in Santa Sabina in Rome. Marburger Jahrbuch für Kunstgeschichte 34: 19-41.

Trout, D. 2015. Damasus of Rome: The Epigraphic Poetry. Oxford: Oxford University Press.

Ullmann, W. 1970. The Growth of Papal Government in the Middle Ages, 3rd ed. London: Methuen.

Webb, M. 2001. The Churches and catacombs of Early Christian Rome. Brighton: Sussex Academic Press.

Wickham, C. 2015. Medieval Rome: Stability and Crisis of a City, 900-1150. Oxford: Oxford University Press.

Wirbelauer, E. 1993. Zwei Päpste in Rome: Der Konflikt zwischen Laurentius und Symmachus (498-514). Munich: Tuduv. 